\title{
Composition and Diversity of Dragonflies (Insecta: Odonata) in Tunan Waterfall Area, North Minahasa, North Sulawesi, Indonesia
}

\author{
Roni Koneri ${ }^{1 *}$, Meis Nangoy ${ }^{2}$ and Pience V. Maabuat ${ }^{1}$ \\ ${ }^{1}$ Department of Biology, Sam Ratulangi University, Indonesia \\ ${ }^{2}$ Department of Animal Production, Sam Ratulangi University, Indonesia
}

\begin{abstract}
A B S T R A C T
Dragonflies play an important role in an ecosystem and can serve as control agents of agricultural insect pests. Dragonflies can be used as bioindicators for evaluating environmental changes in long-term studies (biogeography) and short-term studies (conservation biology). This research study was aimed to analyse the composition and diversity of dragonflies in Tunan Waterfall area, North Sulawesi, Indonesia. Sampling was conducted from March 2018 to May 2018 at at three types of habitat, namely primary forest, secondary forest, and agricultural land. At each habitat type were laid four 300-metre-long transect lines. The lines were placed along the river of each habitat type, and sampling was carried out along the lines using sweep nets. From the research, 7 families, 20 species and 1,750 individuals belonging to 2 suborders, Anisoptera and Zygoptera, were identified. Libellulidae was the family with the most number of species and individuals being found. Th especies with the highest abundance was Orthetrum pruinosum, followed by Libellago xanthocyana. The highest dragonfly species abundance was found in the plantation land, while the lowest was found in the primary forest or around the waterfall. The highest dragonfly richness index, species diversity index (H'), and species evenness index were found in the secondary forest, followed by the primary forest. The diversity of dragonflies at the observation site was influenced by vegetation cover and temperature.
\end{abstract}

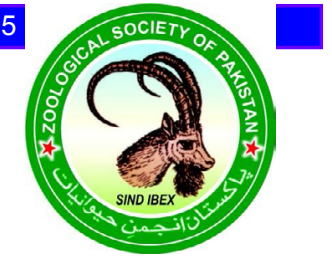

CrossMark tclick for updates

\begin{tabular}{l} 
Article Information \\
Received 14 December 2018 \\
Revised 02 April 2019 \\
Accepted 06 May 2019 \\
Available online 21 August 2020 \\
Authors' Contribution \\
\hline RK planned the research project, \\
collected samples, performed \\
laboratory work and wrote the article. \\
MJN, helped in sampling, analyzed \\
the data and prepared the manuscript. \\
PVM, Proofread the manuscript and \\
helped in data analysis \\
Key words \\
Dragonflies, Diversity index, \\
Zygoptera, Libellago xanthocyana, \\
Canopy
\end{tabular}

\section{INTRODUCTION}

$\mathrm{D}$ ragonflies belong to the class insect, order Odonata, and are generally bright in colours with varied patterns. The body of a dragonfly is made up of a head, a torax, an abdomen, wings, and legs. Dragonflies are widely distributed from forests, lakes, gardens, farmlands, and rivers to house yards and urban environments. It has been recorded that there are 6,000 species, 630 genera, and 28 families of dragonflies worldwide (Kannagi et al., 2016; Varshini and Kanagappan, 2016). Dragonflies are classified into two suborders, namely Zygoptera $(2,739$ species and 19 families) and Anisoptera (2,941 species and 12 families), while roughly 1,000 to 1,500 other species have yet to be described (Mapit-ot et al., 2013).

Tropical regions have high dragonfly species diversity and family number. Twelve out of 31 families live near tropical forest river streams. In Indonesia, 750 dragonfly species have been found, one of which is a species endemic to Sulawesi named Gynacantha penelope Ris (Susanti, 1998). As many as 143 species have been

\footnotetext{
* Corresponding author: ronicaniago@yahoo.com 0030-9923/2020/0006-2091 \$ 9.00/0

Copyright 2020 Zoological Society of Pakistan
}

found in Sulawesi (van Tol, 2000), consisting of 50 species of Zygoptera and 93 species of Anisoptera (van Tol, 1987). The species found in the primary forest were mostly endemic, while those found in other habitats can also be found throughout Southeast Asia (Arai, 1996).

Dragonflies are an important component in biodiversity, and in food web, they act as carnivores and detrivors (Das et al., 2012; Siregar and Bakti, 2016). In all of their life-cycle stages, dragonflies act as predators and eat a wide variety of insects and other organisms. Dragonfly nymphs are predators in the aquatic ecosystem, while adult dragonflies (imagoes) are predators of agricultural crop pests, thus they can be used as natural pest control agents (Kandibane et al., 2005). Dragonflies can also be used as an indicator of forest environment and water quality (Dolny et al., 2011; Das et al., 2012).

Dragonfly community structures are highly sensitive and determined by the conditions and resources present at a habitat. Destruction of a habitat is the most prominent cause of dragonfly population decline (Moore, 2004). The use of dragonflies as a bioindicator is based on the diversity, abundance, and distribution of dragonflies in relation to the physical and chemical conditions of a habitat. Whether a habitat is clean or polluted, the diversity and abundance of insects present will reflect it (Kannagi et al., 2016). 
Some research studies on the diversity of dragonflies have been conducted, including one concerning the diversity of Odonata and its relationship with the ecosystem as an environment indicator (Mapi-ot et al., 2013; Kannagi et al., 2016). Some other studies include a study on the diversity, distribution, and species composition of Odonates in Similipal Tiger Reserve, India (Sunit et al., 2012); a study on the diversity and distribution of dragonflies in the Coalcoman Mountains, Mexico (Anaya et al., 2011); a study on the distribution and diversity of dragonflies in the Kerian River Basin, Kedah, Malaysia (Ameilia et al., 2006); a study on the diversity of Odonates and its relation with ecosystem and land use in Northern Peninsular Malaysia (Siregar et $a l ., 2005)$; and a study on the distribution and diversity of dragonflies in Sekayu Recreational Forest, Terenganu, Malaysia (Afzan and Amirrudin, 2006). Some examples of studies on dragonflies that have been conducted in Indonesia include a study on the presence of Odonata nymphs in various farmland habitats (Ahmad, 1982) and a study on the diversity of Odonata in Asmat Regency and Mappi Regency, Papua (Kaize and Kalkman, 2011). Dolny et al. (2011) studied dragonflies in the Bornean rainforest as an indicator of changes in biodiversity resulting from forest modification and destruction.

Tunan Waterfall is situated in Minahasa Utara Regency, North Sulawesi, and is an ecotourism destination. Various types of habitat in which various dragonfly species live can be found in this area. There has been no published study on the composition and diversity of dragonflies (Order: Odonata) in Tunan Waterfall area, Minahasa Utara, North Sulawesi to date. This research aimed to analyse the composition and diversity of dragonflies at Tunan Waterfall, North Sulawesi, Indonesia.

\section{MATERIALS AND METHODS}

\section{Study site}

This research was conducted from March 2018 to June 2018. The sampling location was Tunan Waterfall area, Minahasa Utara Regency, North Sulawesi (Fig. 1). Sampling was carried out at the watershed, which was divided into at three types of habitat, namely primary forest, secondary forest, and agricultural land. Its habitat was measured for temperature, humidity, vegetation canopy covering, altitude, and coordinates when sampling. Measurement of temperature and humidity using ThermoHigrometer (Dekko 637). Altitude and coordinates were measured using Global Positioning System (Garmin GPSMAP 78s).

Primary forest was a river area near a waterfall with vegetation canopy covering $78-85 \%$ of the area, temperature of $27.2-30.0^{\circ} \mathrm{C}$, and humidity of $79-82 \%$, and was located at an altitude of $140-177 \mathrm{~m}$ a.s.l and coordinates of $01^{\circ} 34^{\prime} 07.80$ " N; 124.58'42.16" E. Secondary forest was situated at a secondary forest with vegetation canopy covering $60-79 \%$ of the area, temperature of $27.3-32.0^{\circ} \mathrm{C}$, and humidity of $75-80 \%$, at was located at an altitude of $125-135 \mathrm{~m}$ a.s. 1 and coordinates of $01^{\circ} 33^{\prime} 52.25^{\prime \prime} \mathrm{N}$; $124 \circ 58$ '28.52"E. Agricultural land was a river stream in a plantation area with vegetation canopy covering $40-50 \%$ of the area, temperature of $29.0-33.0^{\circ} \mathrm{C}$, and humidity of $60-76 \%$, and was located at an elevation of $107-115 \mathrm{~m}$ a.s.l and coordinates of $01^{\circ} 33^{\prime} 30.81^{\prime \prime N}$; $124 \circ 57^{\prime} 56.98^{\prime \prime}$ E.

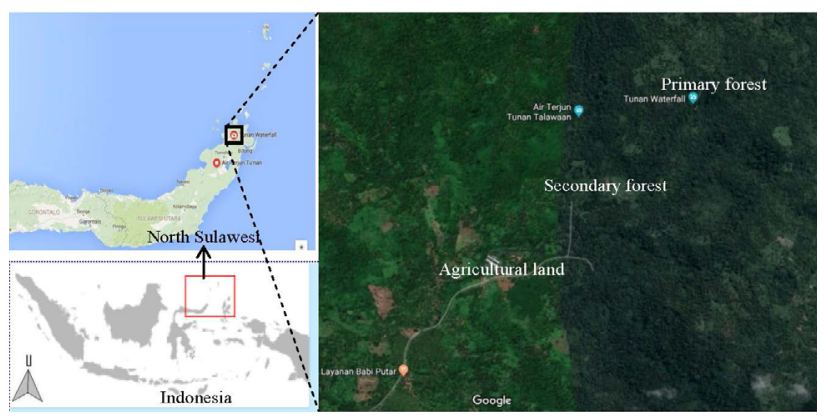

Fig. 1. Lacation of Tunan waterfall and sample sites.

\section{Sampling}

This research used the purposive random sampling method. Sampling was carried out at three habitat types, namely primary forest, secondary forest, and agricultural land. At each habitat type were laid three 300-metre-long transect lines. The lines were placed along the river stream of each habitat type.

The dragonfly sample selected in this research consisted of adult dragonflies (imagoes). Sampling was conducted along the transect lines using insect collecting nets. The nets used were cone-shapped, $60 \mathrm{~cm}$ deep, and $300-380 \mathrm{~cm}$ in diameter, and they had a pole two metres in length. The sampling of dragonflies was conducted monthly for three months from 8 a.m. to 2 p.m. local time. This timing was chosen because dragonflies are a group of insicts that are active during the day. The dragonflies captured were inserted into bottles previously filled with tissue paper and eter. After the dragonflies died, the bodies were taken out from the bottles and then dried in the sun. This was aimed to prevent the iridescent colours of Odonata from fading. Afterwards, they were stored in 30 $\mathrm{cm}$ by $20 \mathrm{~cm}$ triangle-shapped envelopes with the wings folded towards the upper body. Every envelope held one dragonfly.

The sample was subsequently identified based on their morphological characteristics, and the number of 
Table I. Number of suborder, family, species and individual's dragonflies found in three types of habitat from Tunan Waterfall area, North Sulawesi.

\begin{tabular}{|c|c|c|c|c|c|}
\hline \multirow{2}{*}{$\begin{array}{l}\text { Sub order/Family } \\
\text { Species }\end{array}$} & \multicolumn{3}{|c|}{ Number of individuals } & \multirow[t]{2}{*}{ Total } & \multirow[t]{2}{*}{$\%$} \\
\hline & Primary forest & Secondary forest & Agricultural land & & \\
\hline \multicolumn{6}{|l|}{ Sub order: Anisoptera } \\
\hline \multicolumn{6}{|l|}{ Family I: Libellulidae } \\
\hline Orthetrum pruinosum & 22 & 110 & 200 & 332 & 18.97 \\
\hline Diplacina sanguinolenta & 48 & 68 & 42 & 158 & 9.03 \\
\hline Orthetrum sabina & 26 & 49 & 56 & 131 & 7.49 \\
\hline Neurothermis stigmatizans & 3 & 12 & 19 & 34 & 1.94 \\
\hline Diplacodes trivialis & 3 & 4 & 5 & 12 & 0.69 \\
\hline Neurothemis ramburii & 3 & 5 & 2 & 10 & 0.57 \\
\hline Nannophya pygmaea & 3 & 3 & 0 & 6 & 0.34 \\
\hline Orthetrum glaucum & 0 & 1 & 3 & 4 & 0.23 \\
\hline Acisoma panorpoides & 0 & 2 & 0 & 2 & 0.11 \\
\hline Celebothemis delecollei & 1 & 0 & 0 & 1 & 0.06 \\
\hline \multicolumn{6}{|l|}{ Sub order: Zygoptera } \\
\hline \multicolumn{6}{|l|}{ Family I: Coenagrionidae } \\
\hline Libellago xanthocyana & 36 & 111 & 100 & 247 & 14.11 \\
\hline Pseudagrion pilidorsum & 51 & 77 & 87 & 215 & 12.29 \\
\hline Pseudagrion crocops & 0 & 38 & 56 & 94 & 5.37 \\
\hline Teinobasis sp & 19 & 2 & 1 & 22 & 1.26 \\
\hline Libellago daviesi & 12 & 1 & 0 & 13 & 0.74 \\
\hline \multicolumn{6}{|l|}{ Family II: Calopterygidae } \\
\hline Neurobasis kaupi & 80 & 77 & 42 & 199 & 11.37 \\
\hline \multicolumn{6}{|l|}{ Family III: Chlorocyphidae } \\
\hline Rhinocypha frontalis & 105 & 45 & 28 & 178 & 10.17 \\
\hline \multicolumn{6}{|l|}{ Family IV: Platycnemididae } \\
\hline Nososticta flavipennis & 31 & 34 & 4 & 69 & 3.94 \\
\hline \multicolumn{6}{|l|}{ Family V: Argiolestidae } \\
\hline Celebargiolestes orri & 2 & 0 & 17 & 19 & 1.09 \\
\hline \multicolumn{6}{|l|}{ Family VI: Lestidae } \\
\hline Lestes sp & 2 & 2 & 0 & 4 & 0.23 \\
\hline Total & 447 & 641 & 662 & 1750 & 100.00 \\
\hline
\end{tabular}

individuals were counted. The identification process was undertaken based on the external morphological charactersitics by referring to the books by Borror et al. (1992), Watson and Farrel (1991), Miller (1995), Lieftinck (1949), Wilson (1995), Tsuda (2000) and Wang (2000).

\section{Statistical analysis}

The data analysed in this research covered the data of species abundance $(\mathrm{N})$, species richness index $(\mathrm{S})$, species diversity index $(\mathrm{H})$, and species evenness index
(E). All of the indices were calculated with the aid of PAST 2.17 programme (Hammer et al., 2001). To look into the relationship between species diversity and the environment physical-chemical parameter values, a Spearman's correlation test was conducted. This test was conducted with the aid of Statistika version 6 programme (Stat Soft, 2001).

The analysis of the dragonfly community similarity between the habitat types used Sorense's similarity index, and the data used was the data of species presence and 
absence (Magguran, 1988). The index was calculated using Biodiv 97, which was Excel-based macro software (Shahabuddin et al., 2005). The dissimilarity value (1-Sorensen's index) was used to make a cluster analysis (Krebs, 1999; Ludwig and Reynold, 1988). In the cluster analysis, every community was structured hierarchically in the form of a dendrogram. The dendogram was developed using the Statistica for Windows 6 programme (Stat Soft, 2001). The clustering was performed using the unweighted pair group method with arithmetic mean (UPGMA) and Euclidean gap (Lewis, 2001).

\section{RESULTS}

\section{Dragonfly structure and composition}

From the research on dragonflies in Tunan Waterfall area, 2 suborders, 7 families, 20 species, and 1,750 individuals were identified (Table I). The suborders identified included Anisoptera and Zygoptera. The most abundant suborders were Zygoptera (60.57\%) (Fig. 2). Zygoptera showed the highest abundance at every types of habitat (Fig. 2). Anisoptera was only found in one family, Libellulidae, with 10 species. The Zygoptera found consisted of 6 families, namely Coenagrionidae ( 5 species), Calopterygidae, Chlorocypidae, Platycnemididae, Argiolestidae and Lestidae, each with one species (Table I).

Libellulidae was the dragonfly family with the highest species abundance $(39.43 \%)$, followed by Coenagrionidae $(33.77 \%)$. The lowest species abundance was found in the family Lestidae (0.23\%) (Fig. 3). The families Libellulidae and Coenagrionidae were dominant at all types of habitat (Fig. 3).

The dragonfly species with the highest abundance was Orthetrum pruinosum (18.97\%), followed by Libellago xanthocyana (14.11\%). Celebothermis delecollei was the species least frequently found with only one individual found $(0.06 \%)$ (Table I).

The dragonfly species distribution at each habitat showed that as many as 12 species were found at the three types of habitat, with 3 species found at primary forest and secondary forest. A species, Celebargiolestes orri, was found at primary forest and agricultural land. The species exclusively found at primary forest was Celebothemis delecollei, while Acisoma panorpoides was only found at secondary forest (Table I).

\section{Dragonfly species diversity}

The species diversity of dragonflies was observed through species abundance, species richness index, species diversity index, and species evenness index. The highest species richness was found at agricultural land (37.83\%), followed by secondary forest $(36.63 \%)$. The lowest species richness was found at primary forest (25.54\%) (Fig. 4a).
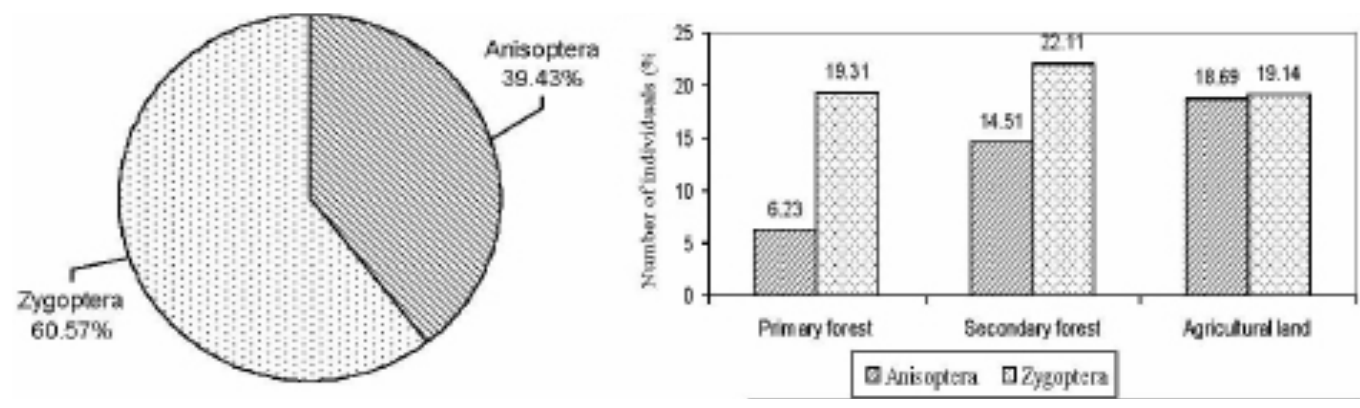

Fig. 2. The abudance of suborder dragonflies found in three types of habitat in Tunan Waterfall, North Sulawesi.
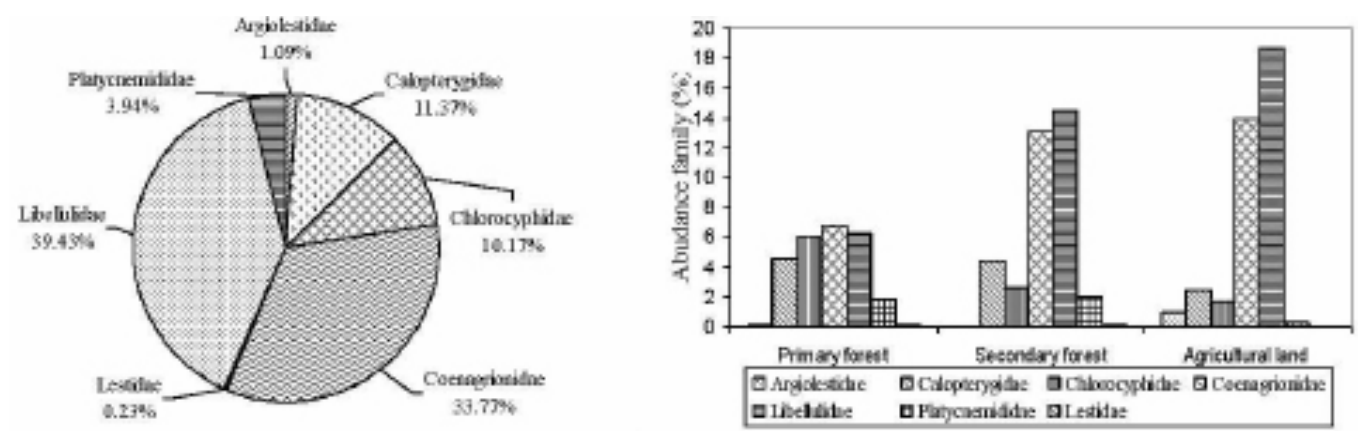

Fig. 3. The abundance of family dragonflies found in three types of habitat in Tunan Waterfall, North Sulawesi. 

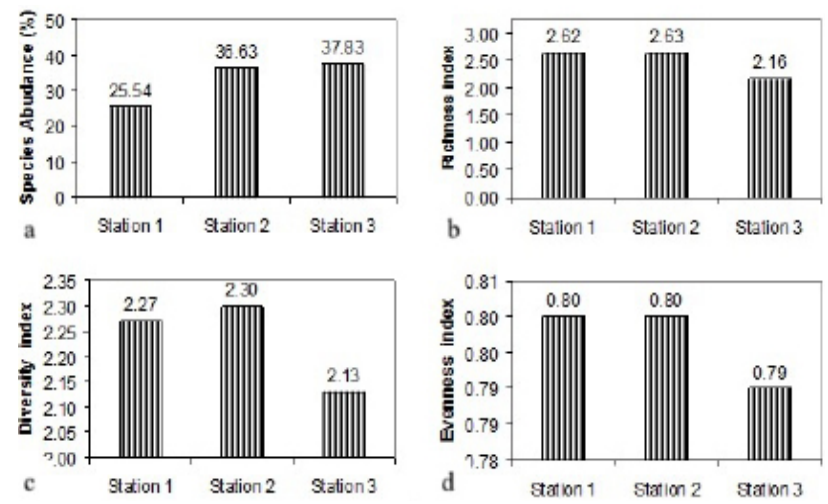

Fig. 4. Species abudance (a), Richness index (b), Diversity index (c) and Evenness index species dragonflies (d) in Tunan Waterfall, North Sulawesi. Station I, primary forest; Station II, secondary forest; station III, agricutural land.

The highest species richness index and species diversity index $\left(\mathrm{H}^{\prime}\right)$ of dragonflies were found at secondary forest, with values of 2.63 and 2.30, respectively. Agricultural land had the lowest species richness index and species diversity index, with values of 2.16 and 2.13, respectively (Fig. $4 \mathrm{~b}$ and $4 \mathrm{c}$ ). The highest species evenness index was found at primary forest and secondary forest (0.80). The lowest, on the other hand, was found at agricultural land (Fig. 4d).

Correlation between dragonfly species and environmental factors

When dragonfly species diversity was correlated with environmental factors, a positive correlation was found between abundance and temperature. This shows that the higher the temperature, the higher the species abundance. Species evenness index and canopy showed a positive correlation. Meanwhile, species richness index and species diversity index showed a low correlation value (Table II).

Table II. Correlation coefficient among dragonflies diversity and environmental factor.

\begin{tabular}{lllll}
\hline Variabel & Canopy & Temperature & Humidity & Altitude \\
\hline Abudance species & -0.51 & $0.69^{*}$ & -0.28 & -0.33 \\
Richness index & 0.10 & 0.19 & 0.26 & -0.04 \\
Diversity index & 0.37 & 0.02 & 0.47 & 0.15 \\
Evenness index & $0.68^{*}$ & -0.51 & 0.57 & 0.46 \\
\hline
\end{tabular}

* Marked correlations are significant at $\mathrm{p}<.05000 ; \mathrm{N}=9$ (Casewise deletion of missing data).

\section{Dragonfly community similarity}

From the observation of the dragonfly community similarity between habitat types, it was found out that primary forest and secondary forest had the highest dragonfly community similarity at $0.86(86 \%)$, followed by the similarity between primary forest and agricultural land $(81 \%)$. The lowest community similarity index was shown between secondary forest and agricultural land (79\%) (Table III).

Table III. Matrix about dragonflies community similarity among types of habitat in Tunan Waterfall area, North Sulawesi.

\begin{tabular}{llll}
\hline Study Site & $\begin{array}{l}\text { Primary } \\
\text { forest }\end{array}$ & $\begin{array}{l}\text { Secondary } \\
\text { forest }\end{array}$ & $\begin{array}{l}\text { Agricultural } \\
\text { land }\end{array}$ \\
\hline Primary forest & 1.00 & 0.86 & 0.81 \\
Secondary forest & 0.86 & 1.00 & 0.79 \\
Agricultural land & 0.81 & 0.79 & 1.00 \\
\hline
\end{tabular}

The dendrogram developed shows that primary forest and secondary forest were of the same group, whereas agricultural land was separated from primary forest and secondary forest (Fig. 5). This means that the dragonfly species composition at primary forest and that at secondary forest shared many in common.

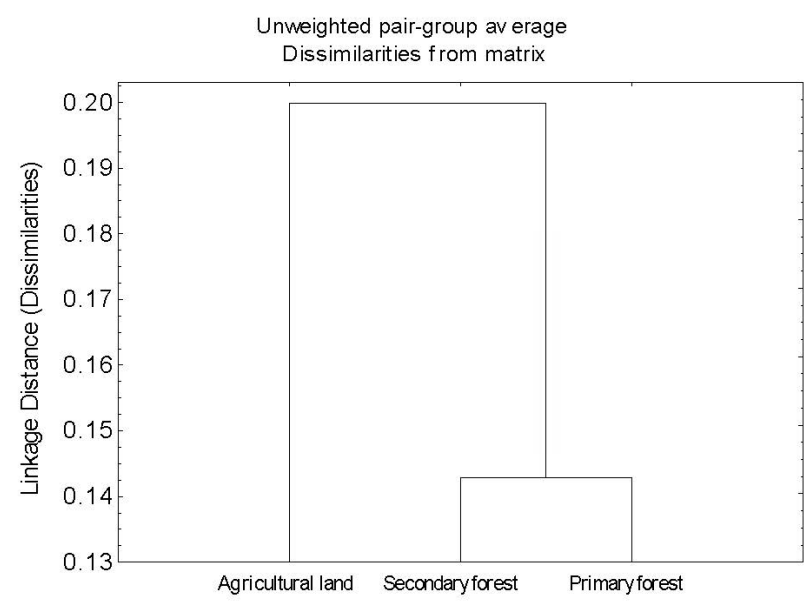

Fig. 5. Dendogram about dragonfly community similarity among habitat in Tunan Waterfall, North Sulawesi.

\section{DISCUSSION}

The number of dragonfly species found in this research only reached $0.33 \%$ of the total number of all species worldwide $(6,000)$ (Kannagi et al., 2016). When compared with the total number of dragonfly species in Indonesia (750 species), it only reached $2.67 \%$, and it reached $13.99 \%$ when compared with the total number of 
dragonfly species across Sulawesi (143 species) (Susanti, 1998; van Tol, 2000). The number of dragonfly species present was higher than the numbers found in some other studies conducted on Sulawesi Island. Koneri et al. (2017) found 15 dragonfly species at Tangkoko Nature Reserve, North Sulawesi, while Nangoy and Koneri (2017) reported that 19 species were found at Bogani Nani Wartabone National Park North Sulawesi. The research by Suriana et al. (2014) around Moramo River and Swamp, Konawe Selatan Regency, Southeast Sulawesi, found more species, namely 28 species, whereas the research by Kaize and Kalkman (2011) in Asmat Regency and Mappi Regency (Papua, Indonesia) found 43 dragonfly species. The differences in the number of dragonfly species collected across research sites were highly influenced by the total area of the observation sites, types of habitat, length of sampling, and sampling techniques used by the researchers. According to Salmah et al. (2006), the distribution and composition of dragonfly species differed between research sites due to habitat suitability, heterogenous vegetation, weather condition during sampling, and biotic, physical, and chemical factors.

Anisoptera was the most dominant suborders found at every habitat types. Some research studies reported that Anisoptera was more frequently encountered than Zygoptera (Seidu et al., 2018; Narender et al., 2016; Dolny et al., 2011; Kaize and Kalkman, 2011). Anisoptera's dominance could be explained by its wider distribution and better adaptation to different types of habitat than Zygoptera's (Arulprakash and Gunathilagaraj, 2010). According to Rahadi et al. (2013), Zygoptera can be found near clean, flowing waters with moderate sunlight intensity or in the shade of trees.

Anisoptera was more frequently found at agricultural land, with a lower percentage of canopy cover and higher temperature than those of primary forest and secondary forest. At primary forest and secondary forest, Zygoptera was predominant. This is due to greater percentage of vegetation canopy cover and lower temperature at primary forest and secondary forest than at agricultural land. According to Narender et al. (2016), the tree and water vegetation canopy near river are much more preferred by Zygoptera than Anisoptera.

The dragonfly families with the most numbers of individuals and species were Libellulidae (Anisoptera) and Coenagrionidae (Zygoptera). Some research studies report that Libellulidae were more frequently found than other dragonfly families (Narender et al., 2016; Siregar and Bakti, 2016; Das et al., 2012).

The families Libellulidae and Coenagrionidae were more abound as they predominate the suborders Anisoptera and Zygoptera. The family Libellulidae is the largest family in the suborder Anisoptera, and its distribution pattern and adaptive abilities are high. The family Coenagrionidae, on the other hand, is the largest family in the suborder Zygoptera, and they are evenly distributed around the world (Orr, 2003). Libellulidae and Coenagrionidae have the widest and largest habitat distribution. These families can virtually be found in any type of habitat and are dominant in unshaded habitats with stagnant water (Kalkman and Orr, 2013). They have the most advanced ability to migrate, have distribution spanning more than one region, and are also found on isolated islands (Kalkman et al., 2008). Another factor causing these families to have the highest abundance is that they have a short life cycle and are more tolerant towards a wide array of habitats (Arulprakash and Gunathilagaraj, 2010). Sharma and Joshi (2007) reported that Libellulidae and Coenagrionidae are predators. The species of these families are usually aggressive and prey on all types of insects. Libellulidae preys on all types of aquatic organisms and pests dominant in food crop lands and plantations whose sizes are fit for consumption.

Orthetrum pruinosum (Anisoptera: Libellulidae) was the species with the highest abundance to be found during the conduct of the research. O. pruinosum was frequently found at agricultural land, which had a low percentage of vegetation canopy. Red and black grey $O$. pruinosum are males. O. pruinosum have transparent-coloured wings with black venation. The torax is composed of three parts, namely protorax, mesotorax, and metatorax in blackish grey with black legs. Their abdomens are predominantly red from the first segment to the last segment and the tail. The $O$. pruinosum in this research were found to be flying near the river and ocassionally perched on the plants growing in the plantation. When the temperature was high, $O$. pruinosum were observed to mostly fly low near water before finally perching on aquatic plants to lower their body temperatures. Adult $O$. pruinosum are flying insects, meaning that they are able to move by means of flight. According to Corbet (1999), some adult dragonfly species in the suborder Anisoptera are flying insects that are able to migrate through a long distance, explaining its distribution. An Anisoptera dragonfly can fly at a speed of 36 km/hour (Amir and Kahono, 2003).

The highest dragonfly species richness index, species diversity index, and species richness index were found at primary forest and secondary forest. Primary forest habitat near a waterfall. The variety of habitats at the two habitat types, including rocky rapids, and the various vegetations encouraged the species diversity of dragonflies. The habitat variety also led to sufficient availability of food for dragonflies' preys, causing the species diversity of dragonflies there to be high. According to Theischinger and Hawking (2006) habitat is directly proportionate with the 
environment physical conditions, meaning that every type of habitat has physical conditions distinct to it, which are also influenced by several factors like vegetation density, canopy coverage, and altitude, all of which also affect the presence and spread of dragonfly species.

Agricultural land had lower species diversity than primary forest and secondary forest. Agricultural land was a river with a low percentage of canopy cover and less varied habitates because near the river, only plantation vegetations and bushes could be found, resulting in lower dragonfly species diversity. Another factor causing the low species diversity was the presence of three dragonfly species dominating the habitat, namely Orthetrum pruinosum, Libellago xanthocyana, and Pseudagrion pilidorsum.

The diversity of dragonfly species was influenced by the the vegetation present along the river stream, food availability, clean water, and light intensity. The vegetation density and lack of disturbance and coversion in the forest caused high diversity of dragonflies (Dolny et al., 2011). Good water quality in the forest and lack of human activities determined the high richness and diversity of dragonflies found. Habitat structures, such as the structure of vegetation, is essential to all dragonfly species (Niba and Samways, 2006).

A number of research studies show that an increase in the vegetation canopy and plant diversity will increase the diversity, richness, and evenness of dragonflies (Chovance et al., 2002). The presence of vegetation in a riparian ecosystem has a significant effect on the behaviours of adult dragonflies, for example, staying in the sun, foraging, roosting, and sheltering (Silva et al., 2010; Buchwald, 1992). Dragonflies also use aquatic vegetation as ovipostion substrates (Buchwald, 1992), laying and inserting their eggs into the stem of emergent plants (Corbet, 1999). What hatch from the eggs are called nymphs. Nymphs used aquatic vegetation for roosting, hiding from predators, and perching to wait their preys (Buchwald, 1992).

The diversity of dragonflies in a habitat is also influenced by the habitat's environmental quality factors, for example, $\mathrm{pH}$, temperature, air humidity, chemical conditions, and food availability (Corbet, 1980). Temperature significantly affects dragonfly diversity. Dragonflies prefer flying at locations with higher temperature (Miller, 1995). Higher temperature is needed for dragonflies' wing movement. Dragonflies' venation work effectively when the temperature exceeds $30{ }^{\circ} \mathrm{C}$. Additionally, a sufficiently high temperature is needed for Odonates' vision. More than $80 \%$ of a dragonfly's brain is used for analysing visual information from its vision. To see an object, such as a prey, the compound eyes of a dragonfly will highly require light (Miller, 1995)

Dragonfly diversity is also affected by air humidity. This is because the biological processes of insects are affected by humidity. The optimum humidity range needed is $73-100 \%$. If the humidity is either too high or too low, the activities and the lives of insects can be inhibited, except for the types of insects normally living in wet environments (Sunjaya, 1970).

The species composition similarity shows that the dragonfly species present at primary forest shared many similarities with those present at secondary forest. The community similarity was highly influenced by substantial similarities in the physical characteristics of the environment (e.g. vegetation structure, temperature, and humidity) between habitat types (Narender et al., 2016).

Celebothemis delecollei, Libellago daviesi, and Lestes sp. are the dragonfly species that can be used as environmental health bioindicators. The three species can only be found in forest habitats with unpolluted aquatic environment. In doing oviposition, adult female dragonflies prefer clear, clean water habitats, and nymphs are vulnerable to polluted water quality (Borror et al., 1992; Jhon, 2001). In general, by the time this research was conducted, the water in Tunan Waterfall area was still clean and unpolluted. The presence of the families Chlorocyphidae, Calopterygidae, and Platycnemididae there proved this. The presence of these three families reflects clean water condition (Afzan et al., 2006).

\section{CONCLUSION}

The highest species abundance was found in the agricultural land, and the lowest was found in the primary forest or around the waterfall. Libellulidae was the dragonfly family with the highest species abundance, and the species most frequently found was Orthetrum pruinosum. The highest species richness index and species diversity index ( $\left.\mathrm{H}^{\prime}\right)$ were found in the secondary forest, followed by the primary forest. When dragonfly species diversity was correlated with environmental factors, a positive correlation was found between abundance and temperature. The community similarity index shows that primary forest had species composition similar to that of secondary forest. The diversity of dragonflies at the research site was highly influenced by canopy cover percentage, temperature, and air humidity of each habitat type.

\section{ACKNOWLEDGEMENT}

Our gratitude is due to the Rector of Universitas Sam Ratulangi Manado who has funded this research through 
the Riset Dasar Unggulan Unsrat (RDUU) scheme with contract number: SP DIPA-042.01.2.400959/2018, dated 5 December 2017: 5742.003.053.525119.

Statement of conflict of interest

The authors declare no conflict of interest.

\section{REFERENCES}

Afzan, A.W., Julia, J. and Amirrudin, A., 2006. Diversity and distribution of dragonflies (Insecta: Odonata) in Sekayu Recreational Forest, Terengganu. $J$. Sustain. Sci. Manage., 1: 97-106.

Ahmad, I., 1982. The presence of Odonata nymphs at several rice field habitats, Undergraduate programme, Bandung Institute of Technology. Bandung.

Ameilia, Z.S., Che Salmah, M.R. and Hassan, A.A., 2006. Diversity and distribution of dragonfly (Odonata: Insecta) in the Kerian River Basin, Kedah-Perak, Malaysia. USU Repository, pp. 14.

Amir, M. and Kahano, S., 2003. Insects of the Halimun Mountain National Park in Western Java. Biodiversity Conservation Project. West Java.

Anaya, J.A.G., Gutierrez, R.N. and Campbell, W.B., 2011. Diversity and distribution of Odonata (Insecta) larvae along an altitudinal gradient in Coalcomán Mountains, Michoacán, Mexico. $J$. trop. Biol. 59: 1559-1577. https://doi.org/10.15517/ rbt.v59i4.3420

Arai, Y., 1996. Adapatation of red dragonflies in Japanese paddy fields. The Nat. Insec., 31: 23-26.

Arulprakash, R. and Gunathilagaraj, K., 2010. Abundance and diversity of Odonata in temporary water bodies of Coimbatore and Salem districts in Tamil Nadu. J. Threat. Taxa., 2: 1099-1102. https:// doi.org/10.11609/JoTT.o2035.1099-102

Borror, D.J., Triplehorn, C.A. and Johnson, N.F., 1992. An Introduction to study of insect. 6 ed, Saunders College Pub., A Division of Holt Rinehaest Winston, Inc.

Buchwald, R., 1992. Vegetation and dragonfly fauna characteristics and examples of biocenological field studies. Vegetation, 101: 99-107.

Chovanec, A., Schiemer, F., Waidbacher, H. and Spolwind, R., 2002. Rehabilitation of a heavily modified river section of the Danube in Vienna (Austria): Biological assessment of landscape linkages on different scales. Int. Rev. Hydrobiol., 87: 183-195. https://doi.org/10.1002/1522$2632(200205) 87: 2 / 3<183::$ A I D IROH183>3.0.CO;2-R
Corbet, P.S., 1980. Biology of Odonata. Annu. Rev. Ent., 25: 189-217. https://doi.org/10.1146/annurev. en.25.010180.001201

Corbet, P.S., 1999. Dragonflies: Behaviour and ecology of Odonata. Cornell University, Ithaca, New York, USA.

Das, S.K., Ahmed, R.A., Sajan, S.K., Dash, N., Sahoo, P.K. and Mohanta, P., 2012. Diversity, distribution and species composition of Odonates in buffer areas of Similipal Tiger Reserve, Eastern Ghats, India. Acad. J. Ent., 5: 54-61.

Dolny, A., Barta, D., Lhota, S., Rusdianto and Drozd, P., 2011. Dragonflies (Odonata) in the Bornean rain forest as indicators of changes in biodiversity resulting from forest modification and destruction. Trop. Zool., 24: 63-86.

Hammer, O., Harper, D.A.T. and Ryan, P.D., 2001. PAST: Paleontological statistics software package for education and data analysis. Palaeontol. Electron., 4: 9.

John, T., 2001. Life history Odonata. School of Botany and Zoology, Australian, National University, Canberra.

Kaize J. and Kalkman, V.J., 2011. Records of dragonflies (Odonata) from Kabupaten Asmat and Kabupaten Mappi (Papua, Indonesia). Suara Serangga Рариа. 5: 99-107.

Kalkman, V.J., Clausnitzer, V., Dijkstra, K.D.B., Orr, A.G., Paulson, D.R. and van Tol, J., 2008. Global diversity of dragonflies (Odonata) in freshwater. Hydrobiologia, 595: 351-363. https://doi. org/10.1007/s10750-007-9029-x

Kalkman, V. and Orr, A., 2013. Field guide to the damselflies of New Guinea. Brachytron. Scholma Druk B.V., Bedum, Netherlands.

Kandibane, M., Raguraman S. and Ganapathy, N., 2005. Relative abundance and diversity of Odonata in an irrigated rice field of Madurai, Tamil Nadu. Zoo's Print J., 20: 2051-2052. https://doi.org/10.11609/ JoTT.ZPJ.1293.2051-2

Kannagi, A., Sivakumar, V. and Santhi, V., 2016. Diversity of dragonflies (Insecta: Odonata) in a deciduous forest of Thoothukudi District, Tamil Nadu, South India. J. environ. Protect. Policy, 4: 5863. https://doi.org/10.11648/j.ijepp.20160403.13

Koneri, R., Nangoy, M.J., Saroyo and Tallei, T.E., 2017. Diversity and community composition of dragonfly (Insecta: Odonata) in Tangkoko Nature Reserve, North Sulawesi, Indonesia. Biosci. Res., 14: 01-08.

Krebs, C.J., 1999. Ecological methodology. Second Edition. Menlo Park: Addison-Wesley.

Lewis,T.O., 2001. Effect of experimental selective 
logging on tropical butterflies. Conserv. Biol., 15: $\quad 389-400 . \quad$ https://doi.org/10.1046/j.15231739.2001.015002389.x

Lieftinck, M.A., 1949. The dragonflies (Odonata) of New Guinea and neighbouring islands. Part VII. Results of the Third Archbold expedition 1938-1939 and of the Le Roux Expedition 1939 to Netherlands New Guinea (II. Zygoptera). Nova Guinea (N.S.) 5: $1-271$.

Ludwig, J.A. and Reynolds., 1988. Statistical ecology; a Primer on methods and computing. Wiley \& Sons. New York.

Magurran, A.E., 1988. Ecological diversity and its measurements. Croom Helm Limited. London. https://doi.org/10.1007/978-94-015-7358-0

Mapi-ot E.F., Taotao, A.U., Nuñeza, O.M., Reagan, J.T. and Villanueva, R.J.T., 2013. Species diversity of adult Odonata in selected areas from Misamis Occidental Province, Philippines. AACL Bioflux, 6: 421-432.

Miller, P.L., 1995. Dragonflies. The Queen's College, Oxford.

Moore, N.W., 2004. Dragonflies status survey and conservation action plan. IUCN/SSC Odonata specialist group IUCN gland, Switzerland. pp. 6

Nangoy, M.J. and Koneri, R., 2017. Dragonfly in Bogani Nani Wartabone National Park North Sulawesi. Asian J. Biodiv., 8: 47-61.

Narender, M., Ahamda, S.A., Pandit, R.S. and Wankhade, V., 2016. Seasonal variation in diversity and abundance of Odonata at Sawanga-Vithoba lake. India. J. Ent., 13: 170-178. https://doi.org/10.3923/ je.2016.170.178

Niba, A.S. and Samways, M.J., 2006. Remarkable elevational tolerance in an African Odonata larval assemblage. Odonatologica, 35: 265-280.

Orr, A.G., 2003. A guide to the dragonfly of Borneo: their identification and biology. Natural History Publication (Borneo) Sdn. Bhd. Kota Kinabalu, Sabah, Malaysia

Rahadi, W.S., Feriwibisono, B. and Nugrahani., M.P., 2013. Dragonfly Wendit, diversity og dragonflies in Wendit, Malang, East Java. Indonesia Dragonfly Society, Malang.

Seidu, I., Nsor, C.A., Dangquah, E. and Lancaster, L.T., 2018. Odonata assemblages along an anthropogenic disturbance gradient in Ghana's Eastern Region. Odonatologica, 47: 73-100

Salmah, C., Rawi, M.D., Tribuana, S.W. and Hassan, A., 2006. The population of Odonata (dragonflies) in small tropical rivers with reference to asynchronous growth patterns. Aquat. Insects, 28: 195-209. https:// doi.org/10.1080/01650420600922315

Shahabuddin, Schulze, C.H. and Tscharnke, T., 2005. Changes of dung beetle communities from rainforests towards sgroforestry systems an annual cultures in Sulawesi (Indonesia). Biodiv. Conserv., 14: 863-877. https://doi.org/10.1007/s10531-0040654-7

Sharma, G. and Joshi, P.C., 2007. Diversity of Odonata (Insecta) from Dholbaha Dam (Distt.Hoshiarpur) in Punjab Shivalik, India. J. Asia Pacif. Ent., 10: 177180. https://doi.org/10.1016/S1226-8615(08)603507

Silva, D.P., De Marco, P. and Resende, D.C., 2010. Adult odonate abundance and community assemblage measures as indicators of stream ecological integrity: A case study. Ecol. Indicat., 10: 744-752. https://doi.org/10.1016/j.ecolind.2009.12.004

Siregar, A.Z., Rawi, C.S. and Ahmad, A.H., 2005. The Diversity of Odonata in relation to ecosystem and land use in Northern Peninsular Malaysia. J. Ilmiah Pertanian Kultura, 40: 106-116.

Siregar, A.Z. and Bakti, D., 2016. Diversity and distribution of Odonata in University Sumatera Utara, Medan, Indonesian. Int. J. Sci. Technol. Res., 5: $229-234$..

StatSoft., 2001. Stastistica for windows, 6.0 statsoft Inc. Tulsa: Oklohoma.

Susanti, S., 1998. The field guide dragonflies. Puslitbang Biologi-LIPI. Bogor. Puslitbang Biologi-LIPI. Bogor, pp. 81.

Sunit, K.R., Ahmed, D., Sajan, R.A., Dash, S.K., Sahoo, N., Mohanta, P., Suhu, H.K., Rout, S.D. and Dutta, S.K., 2012. Diversity, distribution and species composition of Odonates in Buffer Areas of Similipal Tiger Reserve, Eastern Ghat, India. Acad. J. Ent., 5: 54-61.

Sunjaya., 1970. Fundamentals of insect ecology. Faculty of Agriculture. Bogor Agricultural University. Bogor

Suriana, D.A. and Hardiyanti, W.A.D., 2014. Dragonfly (Odonata) stocktaking around river and Moramo Swamp, Sumber Sari Village, Moramo District, South Konawe Regency, South East Sulawesi. Biowallacea, 1: 49-62.

Theischinger, G. and Hawking, J., 2006. The complete field guide to dragonfly of Australia. CSIRO Publishing, Collingwood. https://doi. org/10.1071/9780643094109

Tsuda, S., 2000. A distributional list of world Odonata. Private Publication, Osaka.

van Tol, J., 1987. The Odonata of Sulawesi (Celebes), Indonesia an introduction. Adv. Odonatol., 3: 147155 . 
van Tol, J., 2000. The Odonata of Sulawesi and adjacent island, 5: he genus Protosticta Selys (Platystictidae). Tijdschr. Ent. 143: 221-266. https:// doi.org/10.1163/22119434-99900047

Varshini, R.A. and Kanagappan, M., 2016. A study on the diversity of odonate larvae in a permanent pond Melpalai at Melpuram in Kanyakumari district, Tamil Nadu, India. Int. J. appl. Res., 2: 592-598.
Wang, L.J., 2000. Dragonflies of Taiwan. Jemjem Calendar, Taipei.

Watson, J.A.L. and Farrel, A.F.O., 1991. Odonata. In: Insect of Australia (eds. Naoman et al.) Melboume University Press.

Wilson, K., 1995. Hong Kong dragonfies. An Urban Council Publication, Hong Kong. 